\title{
Analysis of plant macrofossils in goat/sheep faeces from the Neolithic lake shore settlement of Horgen Scheller - an indication of prehistoric transhumance?
}

\author{
Örni Akeret ${ }^{1}$ and Stefanie Jacomet ${ }^{2}$ \\ ${ }^{1}$ Service Cantonal d'Archéologie, Valangines 3, CH-2006 Neuchâtel, Switzerland \\ ${ }^{2}$ Labor für Archäobotanik, Botanisches Institut, Schönbeinstrasse 6, CH-4056 Basel, Switzerland \\ Received January 10,1997/ Accepted June 4, 1997
}

\begin{abstract}
Neolithic lake shore settlement of Horgen Scheller (Switzerland) were analysed for plant macrofossils. Only $51(24 \%)$ of them contained identifiable remains. The most frequent finds were prickles of Rosaceae, probably blackberry (Rubus fruticosus s.l.). This is interpreted as food that was grazed from hedges, woodland edges or clearings in winter or spring. Faeces from summer or autumn are apparently not present. Explanations for this are discussed, among which trans-humance seems most probable.
\end{abstract}

Key words: Food of domesticated animals - Ovicapridae - Faeces - Macrofossils - Neolithic

\section{Introduction}

Goat or sheep faeces have been found in a series of lake shore settlements in the region around the Alps. This is due to the good conditions of preservation in the culture layers below the water table. Until now most botanical analyses were confined to pollen (Troels-Smith 1955; Körber-Grohne 1982; Richard 1986; Clapham and Scaife 1988; Hadorn 1994). Therkorn et al. (1984) mention fruits and leaf fragments of Myrica gale besides pollen. Rasmussen (1993) identified pollen and seeds, fruits and wood.

The purpose of this investigation is to find out more about the food of goats or sheep in the Neolithic period. The questions to be answered are whether the animals were fed or if they grazed outside, and where possible pastures $01 \mathrm{hjböäpdswere} \mathrm{situated.} \mathrm{Only} \mathrm{macrofossils}$ (without wood) were identified. This was done because the interpretation of pollen in dung is problematic for different reasons: pollen is not necessarily derived from the eaten plants. It may only be attached to the surface of other plants, for example on grass under flowering trees or on tree leaves in the flowering season of grasses. (See also the experiments of King (1977), Moe (1983),

Correspondence to: Örni Akeret
Caulton and Gibson (1988) or Vermeeren and Kuijper (1993 (1996))). Pollen can also be added to faeces after deposition, or at least this is supposed by Richard (1986). In his analyses of goat/sheep dung he found a great similarity between the faeces and the sediment ("étrangement similaires"). He suggests that pollen was taken up by fresh dung pellets.

The results of pollen analysis are therefore influenced by pollen that was not a part of the food. In contrast, macrofossils reflect what was really eaten by the animals. The identification of wood however turns out to be difficult, because chewing produces fragments which are in most cases too small to show enough anatomical characters (Rasmussen 1993). Various investigations have shown that seeds and fruits can be identified after passage through the digestive tract of sheep or goats and a proportion of them even keep their viability (Harmon and Keim 1934; Müller-Schneider 1954; Piggin 1978; Bottema 1984).

Together with the goat/sheep dung from Horgen Scheller, twigs, seeds and fruits from the site were also studied (by Pascal Favre) and bones (by Renate Ebersbach). These investigations are part of the research project F $19 / 93$ of the foundation "Mensch-GesellschaftUmwelt" (MGU) of Basel University. The project explores the relations between early systems of domesticated animal husbandry and their environment.

\section{The Horgen Scheller site}

Horgen is situated on the southwestern lake shore of the Zürichsee (Lake of Zürich) (Switzerland). The Zimmerberg mountain range (ca. $600 \mathrm{~m}$ asl) runs parallel to the lake shore (ca. $400 \mathrm{~m}$ asl), followed by the Albis mountain range (ca. $900 \mathrm{~m}$ asl) (Fig. 1).

The Horgen Scheller site (47.16 N/8.35 E) was discovered in 1923, and it gave its name to the Late Neolithic "Horgen Culture". The samples investigated here were recovered during excavations between 1987 and 1990 (Eberli 1993). The Neolithic village was situated at the lake shore. The site was periodically flooded and was occupied during periods of low lake levels. In 


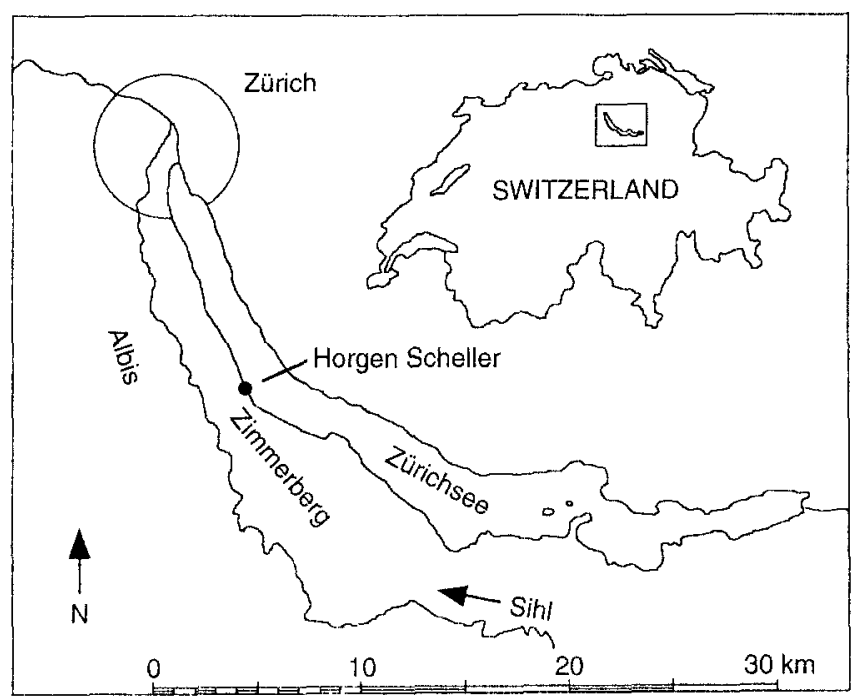

Fig. 1. Location of Horgen Scheller

times of high lake level the settlement layers were covered with water. Three culture layers were recorded (and traces of destroyed layers ("Reduktionshorizont") above them). The culture layers are dated between about 3080 and 3030 B.C. on the basis of dendrochronology. The following tree felling phases could be identified: 3051 $3049,3045 / 3044,3039$ and 3037 B.C. (Quercus with waney edge, that is the wood up to the edge of the bark, E. Gross-Klee according to communications of $\mathrm{Ch}$. Uster and U. Eberli in Stöckli et al. (1995)). All the material studied in this publication originates from layer 3 , which is the uppermost (latest) culture layer. During this period the village reached its greatest extent. This layer contains at least two successive periods of construction. The settlement was probably abandoned due to rising water levels.

The spectrum of branches studied is dominated by Corylus avellana, Abies alba and Taxus baccata (Pascal Favre, personal communication). The proportion of yew (Taxus) is distinctly higher than in other contemporary settlements of the region. The exploitation of yew wood was probably a specialized branch of industry in Horgen. $12 \%$ of the branches (all species) with waney edges were cut during the growing season, $88 \%$ in the winter half year. Species with catkins (Betulaceae, Corylaceae) and conifers were cut mainly in winter, whereas a higher portion of the other species were cut during the growing season.

The analysis of animal bones shows that more than two thirds of the meat came from wild animals, mainly red deer, which is a very high proportion compared with contemporary sites at the Zürichsee (Renate Ebersbach, personal communication). Among domesticated animals goats and sheep contribute only $4 \%$ to the weight of bones in layer 3 . The most important domesticated animals were cattle and pigs. A comparison of the spectrum of pig bones with other sites of the region indicates that meat of this species was imported from other settlements.

\section{Materials and Methods}

The excrements were roundish to elliptic, about $1 \mathrm{~cm}$ long and sometimes showed a little tip at one end (see Fig. 2). Their colour was dark brown to black, the surface often shiny. Waterlogged they weighed 0.01 to $0.12 \mathrm{~g}$. They could not be assigned to either sheep or goat, because it was not known how much the faeces varied according to season and food, and whether shape and size were identical in ancient and modern breeds (see Beeching and Moulin (1983) or Bottema (1984)).

In the publications cited above, only between 3-30 faeces were studied. As the density of seeds and fruits in the faeces turned out to be very low, the comparatively large number of 213 pieces (from 10 different samples) was investigated. First of all the surfaces of the objects were mechanically cleaned from pieces of the surrounding sediment. They were weighed in a waterlogged state and it was noted if they were fragmented or entire. The faeces were broken up and divided with forceps and needle in water under a binocular microscope. Plant fragments were picked out if their identification seemed to be possible. Wood and bark fragments, epidermis and pollen were not sorted out (anthers were not found).

Plant remains were identified by comparison with modern plants in the Basel reference collection. Seeds of Juncus were identified according to Körber-Grohne (1964). Nomenclature follows Binz and Heitz (1990).

\section{Results}

Table 1 shows a summary of the results. 350 macrofossils of 14 taxa have been found (insects and indeterminata not counted). Only 51 of 213 faeces $(24 \%)$ contained identifiable plant remains. Therefore it can be concluded that the food of the goats or sheep was eaten in a season in which only few plants had organs that could still be recognized after passage through the digestive tract. As these organs are mainly seeds and fruits it may be suggested that the faeces are from winter or spring. In the following it will be discussed if this hypothesis can be confirmed by the plants found.

\section{Discussion}

Most of the remains are indeed from plants that can be found during winter, too. The macrofossils most frequently found (in 41 faeces) were prickles of Rosaceae, from Rosa sp., Rubus idaeus, R. fruticosus s.l. or $R$. caesius. Fragments of fruits of Rubus sp. were found in 12 faeces. Among those 8 also contained prickles, which makes Rubus more probable than Rosa. Blackberries ( $R$. fruticosus s.1.) are particularly attractive as food in winter, because they are among the small number of plants in central Europe with perennial leaves. They can be entirely stripped of leaves by goats (Watson 1958). Prickles are also present on leaf veins and petioles and are eaten with them. The prickles found in the faeces were of the same size as those that occur on leaves of Rubus. Finds of Rubus fruits are not contradictory to the winter hypothesis, because dried blackberry fruits are often to be found in winter on the bushes. Other indications for the cold season are bud scales (in 5 faeces) and sporangia of ferns (in 11 faeces; some species of Pteridophyta have 

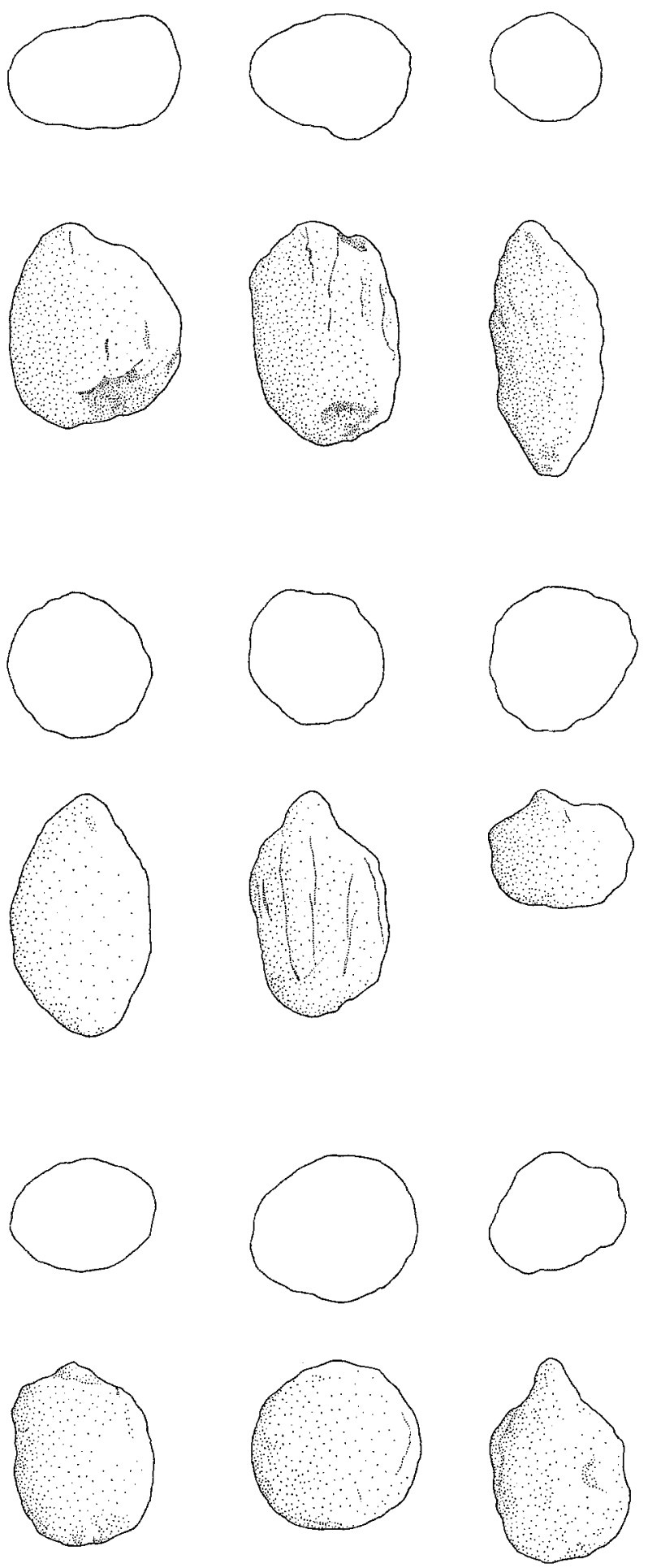

Fig. 2. Goat/Sheep faeces from Horgen Scheller (lateral view and cross section; $\mathrm{bar}=1 \mathrm{~cm}$ )

leaves remaining green in winter, for example some species of Dryopteris, or Polystichum aculeatum, Blechnum spicant, or Polypodium vulgare). However few seeds or fruits were found that are typical of summer or autumn, but they might have been eaten together with dried plants in winter.
The arguments given above do not prove unequivocally that the food came from the winter half year. However one would expect more seeds and fruits from different species in dung from summer or autumn. Harmon and Keim (1934) fed seeds of seven different species to sheep and recovered apparently uninjured seeds of all species in percentages between $7.6 \%$ and $15.4 \%$ in their faeces (fragments that often can be identified in archaeobotanical investigations were not counted in that experiment). Müller-Schneider (1954) lists uninjured seeds of at least 48 species in modern goat faeces and at least 20 in sheep. This shows that fruits and seeds of most plant species can be found in dung after digestion.

Another noticeable point is that none of the frequently found plants (Rubus/Rosa, ferns) grow higher than $2 \mathrm{~m}$. This means that the goats/sheep could have grazed them on their own.

As shown above, the plant remains in the goat/sheep faeces mainly come from food that was grazed outside in the winter half year. It seems obvious that the Neolithic farmers let their animals forage outdoors as long as there was enough food. Bushes with blackberries must have been abundant around lake shore settlements because agriculture and wood cropping produced clearings and woodland edges (Jacomet et al. 1989). Also, the earliest farmers of central Europe probably created hedges (Kreuz 1990). The reason why faeces are found could be that goats and sheep were in or around houses at night for milking or for their protection (see BachmannVoegelin (1984)).

Different explanations are possible for the fact that most of the faeces are from the winter season:

- Only dung from cold seasons was preserved.

- Horgen Scheller was occupied only in winter.

Osteological (R. Ebersbach, personal communication) and archaeobotanical (P. Favre, personal communication) investigations indicate that the site was a special-

Table 1. Macrofossils found in 213 goat/sheep faeces from Horgen Scheller. Number of samples (Sfr) in which the remains concerned are represented and total number of remains (Sum)

Macrofossil Sfr Sum

Rosaceae prickle 115

Rubus sp. fruit

Pteridophyta sporangium

Galeopsis sp. fruit

bud scale

Juncus inflexus seed

Carex sp. fruit

Malus sylvestris pericarp

Papaver somniferum seed

Bryophyta stem

Cerastium sp. seed

Lapsana communis fruit

Poaceae fruit

Polygonum sp. fruit

insects

indeterminata

$\begin{array}{rr}41 & 115 \\ 12 & 71 \\ 11 & 92 \\ 5 & 32 \\ 5 & 13 \\ 4 & 14 \\ 2 & 4 \\ 2 & 2 \\ 1 & 2 \\ 1 & 1 \\ 1 & 1 \\ 1 & 1 \\ 1 & 1 \\ 1 & 1 \\ 7 & 7 \\ 6 & 9\end{array}$


ized settlement. The exploitation of Taxus baccata for trade (in winter?) could have played a central role. However the evidence of deer hunted between April and June proves that inhabitants were not only present in winter.

If the village was occupied the whole year, some kind of transhumance (or "Alpwirtschaft") could have taken place. In summer the animals would have been away from the settlement, maybe in the higher regions of the Zimmerberg or the Albis (see Fig. 1), and only in winter would they have stayed in the warmer regions close to the lake. By this system, places with too much snow in winter could be used in summer and the pastures around the village would be saved for winter. Furthermore the arable land would be protected from goats and sheep in summer.

In contrast to the findings of Horgen Scheller, Rasmussen (1993) presumes that feeding of goats and sheep with twigs played an important role in the Neolithic period. He examined goat/sheep faeces from the Neolithic site of Egolzwil 3 (Canton of Luzern, Switzerland; Egolzwiler Culture; calibrated mean date 4260 B.C. (Stöckli et al. 1995)). Those faeces contained anthers of Corylus (17), of Alnus (2) and of Quercus (1) among other remains. Apparently catkins of these taxa had been eaten. In Horgen no anthers were found. In Egolzwil, on the other hand, there are no indications that the animals pastured outside, especially no prickles of Rosaceae. Their presence in Egolzwil however should not be completely excluded considering that the density of macrofossils in goat/sheep dung can be very low (see Table 1) and that only 13 faeces had been analysed for macrofossils there.

In the culture layers of Horgen Scheller, many fragmented branches and twigs were found. This is also the case in Egolzwil 3 and in other Neolithic lake shore settlements. Some of these branches and twigs, such as the Taxus baccata, may have been a by-product of other activities, and Abies alba may have been used as litter ( $P$. Favre, personal communication). On the other hand twigs of Betulaceae and Corylaceae are good animal fodder. As mentioned above twigs of these species were cut mainly in winter. Rasmussen (1993) reports that from nine Corylus twigs five were harvested in winter, and four in early spring at a time when these species bear catkins that are rich in proteins.

The absence of anthers in Horgen Scheller however leads to the question whether goat/sheep profited from twig fodder. Maybe twigs with catkins in Horgen were reserved for cattle, which need more and better fodder and so have more difficulty surviving the winter. Rasmussen $(1989 \mathrm{a}, \mathrm{b})$ showed that in Weier II Thayngen, Canton of Schaffhausen, Switzerland; Pfyn Culture; felling dates 3722-3715 B.C. (Stöckli et al. 1995)) ruminants, almost certainly cattle, had been fed with leaves and twigs from different tree taxa. It is possible that goats and sheep were fed only when there was too much snow even at lower altitudes, so that they could not find food on their own. Shortage of food might have been a problem mainly at the end of winter when everything around the village was grazed down.
In both places, Horgen and Egolzwil, goats and sheep seem to have been kept outside the village in summer, so that we know nothing about their food in that season.

As we have seen, plant macrofossil analyses of faeces are indispensable for shedding more light upon prehistoric animal husbandry. For this reason the status of the research is completely insufficient up to now. The comparison between the results of Horgen and Egolzwil indicates that there may have been differences in the keeping of small ruminants. At the moment it is not clear if these differences had chronological, regional or cultural reasons. We suppose that the Neolithic farmers tried to make the best of their natural resources: they let their animals forage outside as long as possible, depending on local, climatic and meteorological circumstances, and gave them extra feed when necessary. More work will have to be done to test this hypothesis. Maybe faeces from Arbon Bleiche 3 (Lake Constance, Switzerland), which are being analysed at the moment by the authors, will provide new knowledge.

Acknowledgements. We are most grateful to Renate Ebersbach, Marlu Kühn, Angela Schlumbaum, Jörg Schibler, Pascal Favre and Christoph Brombacher for valuable discussions and helpful comments on the manuscript. The study was financed by the foundation "Mensch - Gesellschaft - Umwelt" (MGU) of Basel University.

\section{References}

Bachmann-Voegelin F (1984) Blatten im Lötschental. Die traditionelle Kulturlandschaft einer Berggemeinde. Haupt, Bern

Beeching A, Moulin B (1983) Sédiments anthropiques et coprolithes animaux: modestes contributions à de grands problèmes? Bull Soc Préhist Fr 80: 72-74

Binz A, Heitz C(1990) Schul- und Exkursionsflora für die Schweiz. Schwabe, Basel

Bottema S (1984) The composition of modern charred seed assemblages. In: Zeist W van, Casparie WA (eds) Plants and ancient man. Studies in palaeoethnobotany. Balkema, Rotterdam, pp 207-212

Caulton E, Gibson W (1988) Etude du contenu pollinique des matières fécales d'herbivores sélectionnés. Inst fr Pondichéry trav sec sci tech 25: 301-308

Clapham AJ, Scaife RG (1988) A pollen and plant macrofossil investigation of Oakbank Crannog, Loch Tay, Scotland. In: Murphy P, French C (eds) The exploitation of wetlands. BAR Br Ser 186, Oxford, pp 293-325

Eberli U (1993) Horgen Scheller. Neolithische Ufersiedlungen am Zürichsee. Lizentiatsarbeit Universität Zürich

Hadorn P (1994) Saint-Blaise/Bains des Dames, 1. Palynologie d'un site néolithique et historique de la végétation des derniers 16000 ans. Musée cantonal d'archéologie, Neuchâtel

Harmon GW, Keim FD (1934) The percentage and viability of weed seeds recovered in the faeces of farm animals and their longevity when buried in manure. J Am Soc Agron 28: 762-767

Jacomet S, Brombacher C, Dick M (1989) Archäobotanik am Zürichsee. Ber Zürcher Denkmalpflege Monogr 7

King FB (1977) An evaluation of the pollen content of coprolithes as environmental indicators. J Ariz Acad Sci 12: 47-52

Körber-Grohne U (1964) Bestimmungsschlüssel für subfossile Juncus-Samen und Gramineen-Früchte. Probl Küstenforsch südl Nordseegeb 7: 1-47 
Körber-Grohne U (1982) Der Schacht in Fellbach-Schmiden aus botanischer und stratigraphischer Sicht. In: Planck D (1982) Eine neuentdeckte keltische Viereckschanze in FellbachSchmiden, Rems-Murr-Kreis. Germania 60: 154-168

Kreuz A (1990) Die ersten Bauern Mitteleuropas. Eine archäobotanische Untersuchung $\mathrm{zu}$ Umwelt und Landwirtschaft der ältesten Bandkeramik. Analecta Praehist Leidensia 23: 1-256

Moe D (1983) Palynology of sheep's faeces: relationship between pollen content, diet and local pollen rain. Grana 22: 105-113

Müller-Schneider P (1954) Über endozoochore Samenverbreitung durch weidende Haustiere. Vegetatio 5-6: 23-28

Piggin CM (1978) Dispersal of Echium plantagineum L. by sheep. Weed Res 18: 155-160

Rasmussen P (1989a) Leaf foddering in the earliest neolithic agriculture. Evidence from Switzerland and Denmark. Acta Archaeol 60: 71-85

Rasmussen P (1989b) Leaf-foddering of livestock in the neolithic: archaeobotanical evidence from Weier, Switzerland. J Danish Archaeol 8: 51-71

Rasmussen P (1993) Analysis of goat/sheep faeces from Egolzwil 3, Switzerland: evidence for branch and twig foddering of livestock in the neolithic. J Archaeol Sci 20: 479-502
Richard H (1986) Analyse pollinique des niveaux archéologiques et des coprolithes. In: Pétrequin $\mathrm{P}$ (ed) Les sites littoraux néolithiques de Clairvaux-les Lacs, Jura. I.: Problematique générale. L'example de la station III. Edition de la Maison des Sciences de l'Homme, Paris, pp 149-153

Stöckli WE, Niffeler U, Gross-Klee E (eds) (1995) SPM II: Neolithikum. Verlag Schweizerische Gesell Ur- Frühgesch, Basel

Therkorn LL, Brandt RW, Pals JP, Taylor M (1984) An early Iron Age farmstead: site $Q$ of the Assendelver Polders project. Proc Prehist Soc 50: 351-373

Troels-Smith J (1955) Pollenanalytische Untersuchungen zu einigen schweizerischen Pfahlbauproblemen. In: Guyan WU (ed) Das Pfahlbauproblem. Monogr Ur- und Frühgesch Schweiz 11: $11-68$

Vermeeren C, Kuijper W (1993 (1996)) Pollen from coprolites and recent droppings: useful for reconstructing vegetations and determining the season of consumption? Analecta Praehist Leidensia 26: 213-220

Watson WCR (1958) Handbook of the Rubi of Great Britain and Ireland. Cambridge University Press, Cambridge 